\title{
WAPL Gene
}

National Cancer Institute

\section{Source}

National Cancer Institute. WAPL Gene. NCI Thesaurus. Code C114734.

This gene is involved in both DNA replication and sister chromatid cohesion. 